\title{
The Effect of Simvastatin and Virgin Coconut Oil (VCO) Combination Therapy as Triglyceride Plasma Lowering Agent in White Dyslipidemic Male Rat (Rattus norvegicus)
}

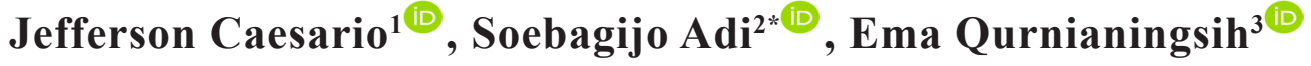 \\ ${ }^{1}$ Faculty of Medicine, Universitas Airlangga, Surabaya, Indonesia \\ ${ }^{2}$ Department of Internal Medicine, Faculty of Medicine, Universitas Airlangga - Dr. Soetomo Academic Hospital, Surabaya, \\ Indonesia \\ ${ }^{3}$ Department of Biochemistry, Faculty of Medicine, Universitas Airlangga, Surabaya, Indonesia
}

\section{A R T I C L E I N F O}

\section{Article history:}

Received 15 August 2021

Received in revised form 11

October 2021

Accepted 21 October 2021

Available online 31 October 2021

\section{Keywords:}

Dyslipidemia,

Triglyceride,

Simvastatin,

Virgin coconut oil.

\section{*) Corresponding author:}

soebagijo.adi.s@fk.unair.ac.id

\begin{abstract}
A B S T R A C T
Introduction: Dyslipidemia is a major health problem in Indonesia which leads to other diseases. Triglycerides (TG) is one of the increased lipid fractions which is related to dyslipidemia. Simvastatin is the main therapy in Indonesia to lower TG levels. The use of virgin coconut oil (VCO) becomes popular as a blood cholesterol-lowering agent even though the effects on TG level remains elusive. Since there is no empirical evidence VCO as a complementary therapy of simvastatin on TG levels, this experimental trial is conducted to determine the effect of simvastatin and VCO combination therapy on blood TG levels in dyslipidemic male white rats.

Methods: 42 white rats (Rattus norvegicus) divided into 5 treatment groups and preliminary test of dyslipidemia. The blood was collected intracardially and TG level was measured by using spectrophotometric methods. Independent variables are simvastatin and VCO and combination therapy while the dependent variable is TG levels of white rats. The data was afterwards analyzed using Mann-Whitney U test.

Results: The control group's triglyceride plasma level, receiving standard diet, is $59 \pm 13,4 \mathrm{mg} / \mathrm{dl}$. The VCO-only group shows $72 \pm 35,4 \mathrm{mg} / \mathrm{dl}$ while simvastatin-only group shows $61,9 \pm 22,6 \mathrm{mg} / \mathrm{dl}$ triglyceride level. Combination therapy of simvastatin and VCO shows $62,3 \pm 31,3 \mathrm{mg} / \mathrm{dl}(\mathrm{p}>0,05)$. Conclusion: There were no significant differences between groups with control. However,the use of VCO with particular dose and duration of therapy, will significantly decrease triglyceride level in the blood as effective as simvastatin. VCO has no efficacy while used as combination therapy of simvastatin.
\end{abstract}

\section{Introduction}

Dyslipidemia, a lipid metabolism disorder characterized by changes in lipid fraction in plasma, has reportedly been one of the triggers of several degenerative diseases such as hypertension, cardiovascular disease, stroke, and diabetes.Lifestyle such as excessive diet, lack of exercise, smoking, and alcohol consumption, plays a major role in the change of lipid fractions. ${ }^{1}$ Triglyceride (TG), low density lipoprotein (LDL), and high density lipoprotein (HDL) are the major lipid fraction which change in dyslipidemia. Hypertriglyceridemia, accompanied by high LDL and low HDL, cause cardiovascular diseases, diabetes, and obesity, while hypertriglyceridemia itself causes pancreatitis. ${ }^{2,3}$ In Indonesia, borderline TG level (150-199 mg/dl) contributes to $13 \%$ of the population whilst high $(200-499 \mathrm{mg} / \mathrm{dl})$ and very high TG level (>500 mg/dl) are about $11.9 \%$ combined. This phenomenon can happen because the detection of dyslipidemia is often very limited regarding to the level of awareness of the community which is still low and perhaps also because the awareness of the doctor in charge of examining lipid profiles in the group at risk of developing dyslipidemia is still low. ${ }^{4}$

Simvastatin has become the primary drug of choice as lipid lowering agent in the last decade because of its capability to repair the lipid fractions and also prevent cardiovascular risks. ${ }^{5,6}$ The increase dose of simvastatin twice will only increase $6 \%$ effectivity of lipid lowering agent and sometimes many patients cannot reach the targeted lipid plasma level. However, the side effects of simvastatin such as rhabdomyolysis and destruction of hepatocytes due to its 
metabolism using cytochrome 2C8 enzyme is unavoidable. Combination therapy of simvastatin and ezetimibe or fibrate will effectively repair the lipid level but the side effect to the liver will continuously increase. ${ }^{7}$ Virgin coconut oil (VCO) which can be produced by grinding, drying, and extracting processes of coconut meat, milk, or residue is lately utilized as ketogenic diet.Medium-chain triglycerides (MCT) inside $\mathrm{VCO}$, is empirically able to reduce cholesterol levels and increase HDL levels as effectively as simvastatin, VCO also has been known for decreasing the risk of obesity, coronary heart disease, and atherosclerosis. ${ }^{1}$ However, the effect of VCO to TG level remains elusive and there are some potential occasions where people consume VCO as their diet while receive simvastatin medication or clinicians who prescript simvastatin medication and VCO as the diet. ${ }^{1,8}$ Therefore; an experiment is essentially needed to prove the effectiveness of VCO and combination therapy of simvastatin and VCO as the TG lowering agent.

\section{Methods}

\section{Aminal Experiment}

This research was an experimental study with post-test only control group design. Conducted in the Animal Experimental Unit of Pharmacology Laboratory, Faculty of Medicine Universitas Airlangga from August until September 2018, this study was started by randomizing 42 male white rat Rattus norvegicus, which were obtained from animal model breeding of the laboratory at 3-4 months age. The animals were acclimatized at room temperature (25$30^{\circ} \mathrm{C}$ ) for a 7 days adaptation period and had access to standard foods and water ad libitum. The standard foods given have a composition of $13-15 \%$ protein, minimally $3 \%$ fat, maximally $8 \%$ fiber, and at most $6 \%$ ash and other micronutrients. After 7 days of adaptation, healthy male rats from 3-4 weeks were used for prior control and treatment groups. Each treatment group $(n=7)$ was given a highfat diet (HFD) for 21 days. The HFD has a composition of $25 \%$ of the pig's brain dissolved in water and given 2 $\mathrm{ml}$ each day according to the reference stating that the pig brain contains a fairly high fat composition. ${ }^{9} 21$ days after administration of HFD, one of the treatment groups was taken to be classified as a preliminary group $\mathrm{K} 0$ then terminated and their blood triglyceride levels observed. The result will be used for measuring the elevation of TG level after the administration of HFD. In addition, the prior controlgroup was also terminated to find normal TG levels in white mice and compare them with the preliminary group. Subsequently, 3 cc of blood was withdrawn intracardially and the TG level was checked. (Figure 1)

\section{Anti-Hyperlipidemia Treatment}

On the 29th day after HFD administration, rats in the remaining 4 groups were treated according to their respective groups. The $\mathrm{K}+(7$ rats) control group will be left with high fat + aquades for 7 days. $\mathrm{K} 1$ group ( 7 rats) will be given HFD and simvastatin $0.2 \mathrm{mg} /$ day for 7 days. The K2 group (7 rats) will be given a high-fat feed with coconut oil VCO $1 \mathrm{~mL} /$ day for 7 days. While the K3 group (7 rats) will be given a high-fat feed then followed by simvastatin $0.2 \mathrm{mg} /$ day and VCO $1 \mathrm{~mL} /$ day for 7 days. In K3 group the administration of simvastatin will be done 1 hour before VCO administration. Simvastatin is given to rats in the form of a suspension made by mixing $40 \mathrm{mg}$ of simvastatin (4 tablets of simvastatin 10mg) with $1 \mathrm{~g}$ of CMC Na and 100 $\mathrm{ml}$ of aquades to obtain a suspension of $0.4 \mathrm{mg} / \mathrm{ml}$. In order to obtain the desired dose, each day the mice were rounded with simvastatin with the amount of $0.5 \mathrm{ml}$. On the 35 th day, the blood will be collected intracardially to calculate blood triglyceride levels. Calculation of blood triglyceride levels using a fully automated chemistry analyzer BS-300 (Mindray Bio-Medical Electronics Co, Shenzhen, China) 10 and displayed to computer devices connected to the spectrophotometry.Blood sample were taken through intracardiac.

\section{Data Analysis}

The TG level is data ratios and becomes dependent variable while independent variable are the administration of simvastatin, VCO and combination therapy.The analytical software was PASW statistics 18 and the data then is analyzed with normality test Saphiro-Wilk and we found that the data is not normally distributed. The significance between group tests using the non-parametric test Kruskal-Wallis followed by Mann-Whitney $U$ with $p<0,05$ considered as statistically significant.

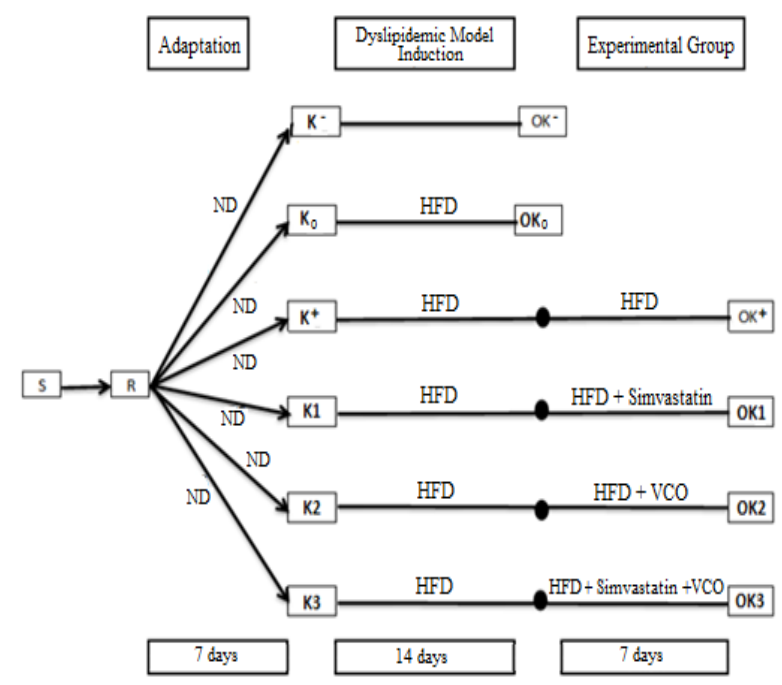

Figure 1. Diagram of experimental model. S: Sample, R: Ramdomization, ND: normal diet, HFD: high fat diet, K: negative control group receiving ND for 21 days, K0 : preliminary group receiving HFD for 14 days to check dyslipidemic model TG level, K1 : positive control group dyslipidemic model without treatment, K1: dyslipidemic model receiving simvastatin, $\mathrm{K} 2$ : dyslipidemic model receiving $\mathrm{VCO}$, and $\mathrm{K} 3$ : dyslipidemic model receiving simvastatin and VCO.

\section{Results}

\section{Triglyceride Level of Rats}

The results of rat blood triglycerides for the preliminary test for 28 days $\mathrm{K}$-, $\mathrm{K} 0$ (table 1 ). The preliminary test shows that the 21 days diet of HFD will significantly increase the blood TG level more than 2 times. In another way, we can say that the treatment of HFD for 21 days can make the rats become hyperlipidemia or dyslipidemia. Therefore; the experiment continued to the 4 treatment groups with assumption that all rats are dyslipidemia. 


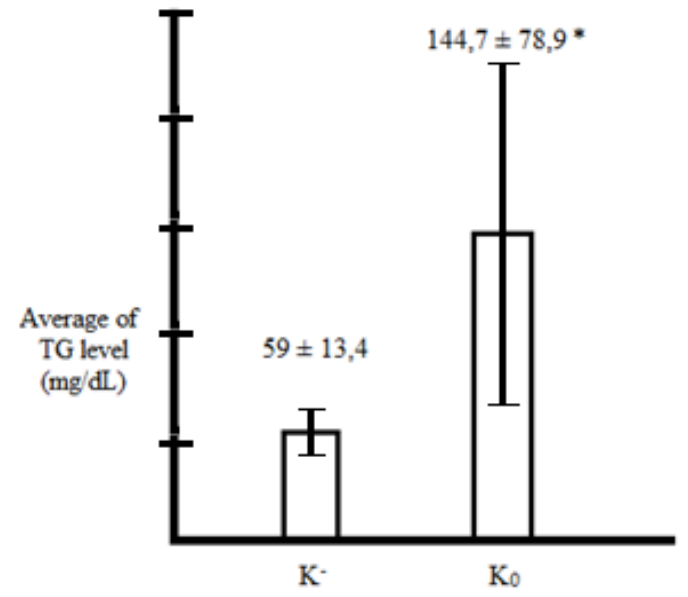

Figure 2. Results of preliminary test of blood triglyceride level

$\mathrm{K}$ - : negative control

$\mathrm{K} 0$ : preliminary test to ensure the dyslipidemic subject.

* $: \mathrm{p}=0.003$. Significant, significantly different at level $\mathrm{p}=0.05$

After the 35th day, an examination of TG levels in the

Table 1. The blood triglyceride levels in white rats

\begin{tabular}{ccccccc}
\hline Groups & Average of TG level $(\mathrm{mg} / \mathrm{dL})$ & $\mathrm{K}-$ & $\mathrm{K}+$ & $\mathrm{K} 1$ & $\mathrm{~K} 2$ & $\mathrm{~K} 3$ \\
\hline $\mathrm{K}-$ & $59 \pm 13,4$ & - & & & & \\
\hline $\mathrm{K}+$ & $63 \pm 22,6$ & $1 \mathrm{~ns}$ & - & & \\
\hline $\mathrm{K} 1$ & $72 \pm 35,4$ & $0,847 \mathrm{~ns}$ & $0,608 \mathrm{~ns}$ & - & \\
\hline $\mathrm{K} 2$ & $61,9 \pm 22,6$ & $0,949 \mathrm{~ns}$ & $0,701 \mathrm{~ns}$ & $0,608 \mathrm{~ns}$ & - & \\
\hline $\mathrm{K} 3$ & $62,3 \pm 31,3$ & $0,949 \mathrm{~ns}$ & $0,701 \mathrm{~ns}$ & $0,482 \mathrm{~ns}$ & $0,609 \mathrm{~ns}$ & - \\
\hline
\end{tabular}

remaining 4 groups, namely group $\mathrm{K}+, \mathrm{K} 1, \mathrm{~K} 2, \mathrm{~K} 3$ is held. Those groups were given high-fat feed, and continued with 4 different treatments (table 1).

The result showed that negative control and positive control groups had no significance. The average value of positive control $\mathrm{K}+$ was not included as dyslipidemia and it showed that there are other factors that influenced the plasma TG level in the 7 days treatment. Comparing the K1 and $\mathrm{K} 2$ groups, we can assume that $\mathrm{VCO}$ and simvastatin has no significant difference for becoming the TG lowering agent. However the K1 TG level was higher $(72 \pm 35,4$ $\mathrm{mg} / \mathrm{dl})$ than $\mathrm{K} 2(61,9 \pm 22,6 \mathrm{mg} / \mathrm{dl})$ which indicated that simvastatin can be said to be the better therapy. Comparing $\mathrm{K} 3$ with $\mathrm{K} 2$, there was no significant difference between the two groups. The TG level of $\mathrm{K} 3(62,3 \pm 31,3 \mathrm{mg} / \mathrm{dl})$ and $\mathrm{K} 2(61,9 \pm 22,6 \mathrm{mg} / \mathrm{dl})$ showed a really small difference between the two groups. That result means there is no significant efficacy for using VCO as combination therapy of simvastatin. From a different perspective, It can also be said that VCO has no adverse effect on TG level if it is used as combination therapy.

$\begin{array}{ll}\text { K- } & \text { : Negative control } \\ \text { K+ } & \text { : Positive control (HFD for } 21 \text { days, HFD+aquadest } 7 \text { days) } \\ \text { K1 } & \text { : VCO treatment (HFD for } 21 \text { days, HFD+VCO } 7 \text { days) } \\ \text { K2 } & \text { : simvastatin treatment (HFD for } 21 \text { days, HFD+simvastatin } 7 \text { days) } \\ \text { K3 } & \text { : combination treatment (HFD for } 21 \text { days, HFD+VCO+simvastatin } 7 \text { days) } \\ \text { ns } & \text { : not significant, not significantly different at level } p=0.05\end{array}$

\section{Discussion}

The Differences of triglyceride level in the simvastatin + VCO combination therapy group (K3) and positive control $(\mathrm{K}+)$ group were found to be insignificant in table 2. Comparing the data of TG levels, it seems that combination therapy group were among the result of the VCO-only therapy group (K1) and simvastatin-only group (K2) although the results of the data analysis in Table2 showed no significant difference between K3 and $\mathrm{K} 1, \mathrm{~K} 2$ groups. The results of the decrease in $\mathrm{TG}$ levels of $\mathrm{K} 3$ gave results that can be interpreted as the average therapeutic effect between simvastatin and VCO. According to the results of another study, it was found that the therapeutic effect of simvastatin was better when compared with VCO in the parameters of decreasing total cholesterol and LDL cholesterol and increasing HDL levels. ${ }^{1}$ Therefore, the use of VCO as combination therapy for simvastatin as TG lowering agent is expected to reduce the efficacy of simvastatin itself. However, we demonstrated that the combination therapy did not remarkably lower TG levels better than simvastatin only.
It should be understood that VCO has a different therapeutic mechanism than simvastatin in repairing fat fraction. VCO contains $8 \%$ MCT which will be absorbed by the intestine and broken down in the liver as an energy source. VCO will be minimally stored in adipose tissue even in the blood vessel, therefore; it can reduce cardiovascular risk and other metabolic diseases. ${ }^{11,12}$ VCO effect on reducing TG level is due to the pancreatic lipase controlling ability. The enzyme that can break down fat and easily be absorbed by the intestine is upregulated by MCT. MCT oil also reduces hepatic TG synthesis by lowering hepatic lipogenic enzyme activity, increasing hepatic lipolytic enzyme activity, and lowering serum TG. However, reducing the percentage of oil in the diet may have the same effect as replacing it with MCT oil. Thus, MCT reduced body fat more effectively with a low-fat diet. ${ }^{12}$

The results of TG levels obtained from preliminary groups (table 1) were statistically significant. This shows that dyslipidemia models using HFD for 21 days were successful. Similar findings other studies stating that by giving HFD with a composition of 5\% yolk, $10 \%$ lard, and 
$1 \%$ cooking oil mixed into standard feed for 4 weeks, will increase rat TG levels into $153.51 \pm 5.40 \mathrm{mg} / \mathrm{dl} .{ }^{10}$ Although no measurements were made on rat blood TG levels, another experimental pre-post control group design of high-fat foods with a mixture of 9:1 standard feed and lard for 14 days showed a significant change of cholesterol level $(10.7 \%)$ and LDL level $(55.52 \%) .{ }^{1}$ This shows that HFD feeding can cause significant changes in fat fractions such as total cholesterol, LDL, HDL, and also TG.

The comparison between positive control group and the group perceiving VCO only which has no significant difference. Moreover, the increase of blood TG level can also be concluded from another study which stated that mixing VCO with standard feed with a ratio of $5 \mathrm{ml} / \mathrm{kg}$ and $10 \mathrm{ml} / \mathrm{kg}$ for 4 weeks could not decrease in rat blood triglyceride levels. ${ }^{8}$ Whereas, another literature study showed a significant decrease in triglyceride levels from $153.51 \pm 5.40 \mathrm{mg} / \mathrm{dl}$ which was indicated as dyslipidemia to $91.46 \pm 5.56 \mathrm{mg} / \mathrm{dl}$ after the use of VCO $0.8 \mathrm{ml} / 200$ gram dose/day for 28 days. The absence of differences between the positive control group and the group receiving VCO only in this study can be due to the need for a longer treatment duration of VCO treatment for these white rats. The time range of $\mathrm{VCO}$ administration which is 1 week is assumed to be less significant in reducing TG levels. ${ }^{1,8,13}$

The simvastatin-only group when compared to the positive control group showed an insignificant difference in the TG levels. The dose of simvastatin used in mice has also been converted using the Laurence and Bacharach conversion table, which is $0.2 \mathrm{mg} /$ day. ${ }^{14}$ This result is different from the effects of simvastatin's pharmacological therapy which are well-known to decrease blood TG and LDL level and significantly increase in HDL level. ${ }^{11}$ Rats also have HMG-CoA reductase enzymes that are present in the liver and small intestinal mucosa that are capable of synthesizing cholesterol and can be inhibited by simvastatin. This effect and mechanism of simvastatin works similarly between humans and rats. ${ }^{15,16}$ The reason that probably explained this phenomenon was the additional period for the rats receiving HFD led to ketogenic diet. Ketogenic diet in rats can lower the triglyceride plasma level. ${ }^{16}$

According to the reference normal levels of TG in rats are $25-145 \mathrm{mg} / \mathrm{dl}$ while the levels in the negative control group were very far from the upper limit. ${ }^{17}$ Besides that, the results of TG levels in the showed a very significant difference when compared with the preliminary test group. The positive control rats received the same treatment as preliminary test group (K0) but was given an additional placebo in the form of aquadest and added the duration of treatment for high-fat feed for 7 days might experience the effect of the placebo effect which can also happen not only in humans but also in rats. ${ }^{18}$ The placebo effect is a positive impact obtained because the psychological response of the brain exceeds that of certain specific effects of a drug. These effects affect several areas of the cortex in the brain such as the lateral medial prefrontal cortex, the ventral striatum, and the brain stem associated with psychological regulation. The placebo effect is thought to play a large role in decreasing TG levels due to psychological responses in areas of the brain that respond as if there was fat reduction therapy. ${ }^{19}$

\section{Conclusion}

We can conclude that VCO, with particular dose and duration of therapy, will decrease total cholesterol level in the blood, however, VCO has no significant difference from simvastatin in lowering TG level. VCO has no efficacy if it is used as combination therapy of simvastatin. The next study is needed to prove the exact dose and duration of therapy administered to maximize the efficacy of VCO as triglyceride lowering agent.

\section{Acknowledgement}

We would like to thank Dr. Soetomo General Academic Hospital for facilitating the continuity of the research. We also thank the medical personnel who took care of the patients and were involved in the management of the research isolates.

\section{Conflict of Interest}

The author stated there is no conflict of interest

\section{References}

1. Harini M., Astirin OP. Blood Cholesterol Levels of Hypercholesterolemic Rat (Rattus norvegicus) after VCO Treatment. Nusantara Bioscience. 2009; $1: 53-58$.

2. Jacobson T, Miller M, and Schaefer E. Hypertriglyceridemia and Cardiovascular Risk Reduction. Clinical Therapeutics. 2007; 29(5): 763777

3. Pramono, Laurentius A, Dante S, Harbuwono. Managing Hypertriglyceridemia in Daily Practice. Acta Medica Indonesiana - The Indonesian Journal of Internal Medicine. 2015; 47 (3)

4. Kementerian Kesehatan RI. Riset Kesehatan Dasar 2013. 2013 [cited 2018 Okt 19] . Available from: URL : http:/www.depkes.go.id/resources/ download/general/Hasil\%20Riskesdas\%202013.pdf

5. Perhimpunan Dokter Spesialis Kardiovaskular Indonesia. Pedoman Tatalaksana Dislipidemia. 2013.

6. Perkumpulan Endokrinologi Indonesia. Panduan Pengelolaan Dislipidemia di Indonesia 2015. 2015.

7. Tjokroprawiro A, Setiawan PB, Effendi C, Santoso D, Soegiarto G. Buku Ajar Ilmu Penyakit Dalam edisi 2. 2015.

8. Yuniwarti and Enny YW. Kadar Trigliserid Tikus Putih Setelah Pemberian Berbagai Kadar VCO dan Olive Oil. Buletin Anatomi dan Fisiologi. 2015; XXIII(2).

9. Sadzikowski MR, Sperry JF, Wilkins TD. Cholesterol-Reducing Bacterium from Human Feces. Applied and Environmental. 1977; Oct 1977, p 355-362.

10. Tang H, Gui M, Bin Y. The Influence and Preventive Measures for the Test Result of Total Bile Acid about Blood Lipid Testing Reagent. Journal of Medical Research. 2006.

11. Katzung BG, Masters SB, Trevor AJ. Basic \& Clinical Pharmacology. Mc Graw Hill Lange. 2012.

12. Nagao K. and Yanagita T. Medium-chain Fatty Acids: Functional Lipids for the Prevention and Treatment of the Metabolic Syndrome. Pharmacological Research.2010;61(3),pp.208-212.

13. Venty A, Made AI, Pangkahila W. Efek Pemberian Virgin Coconut Oil (Cocos nucifera) terhadap Dislipidemia pada Tikus Putih (Rattus norvegicus) Jantan Galur Wistar yang Diberi Diet Tinggi Kolesterol. Warmadewa Medical Journal. 2017; 1(2), p.58.

14. Laurence DR, Bacharach AL. Evaluation of Drug Activities:Pharmacometrics. Academic Press. 1964. Volume 1.

15. Shefer S, Hauser S, Mosbach EH. HMG CoA reductase of Intestinal Mucosa and Liver of the Rat. Journal of Lipid Research. 1972;13.

16. Badman, M., Kennedy, A., Adams, A., Pissios, P. and Maratos-Flier, E., 2009. A Very Low Carbohydrate Ketogenic Diet improves Glucose Tolerance in ob/ob mice Independently of Weight Loss. American Journal of Physiology-Endocrinology and Metabolism, 297(5), pp.E1197-E1204..

17. Smith, J.B. dan S. Mangkoewidjojo. Pemeliharaan, Pembiakan dan Penggunaan Hewan Percobaan di Daerah Tropis. UI Press. 1988; 37- 57.

18. Herrnstein. Placebo Effect in the Rat. Science. 1962

19. Wager T, Atlas L. The neuroscience of placebo effects: connecting context, learning and health. Nature Reviews Neuroscience. 2015; 16(7), pp.403-418. 